from wind turbines may become relevant. In one session the potential impacts of this infrastructure, and regulatory frameworks to minimize collisions, were presented. Additionally, as there has been large-scale loss of intertidal flats in the Yellow Sea (Frontiers in Ecology and the Environment, 2014, 12, 267-272), there was discussion of a potential transboundary offsetting scheme across the flyway, as well as on researching the feasibility of habitat restoration.

The meeting indicated that the East Asian-Australasian Flyway Partnership is now gathering momentum and transitioning from negotiation to implementation. The event concluded with an agreed work plan for 2015-2016, which partners will report against at the next meeting in 2017, tentatively to be held in Singapore. For access to the full minutes of the meeting see http://www.eaaflyway.net

EDUardo Gallo-Cajiao and Richard A. Fuller School of Biological Sciences, The University of Queensland, St Lucia, Queensland, Australia.E-mail e.gallocajiao@uq.edu.au

\section{Large fires in the Andean Araucaria forests: when a natural ecological process becomes a threat}

The fire season of 2014-2015 in Chile has been one of the worst of the last 50 years, with large and simultaneous fires affecting vast areas of Andean Araucaria-Nothofagus forests in several national parks, forest reserves and private properties. The worst-affected protected areas are China Muerta and Malleco National Reserves, and Conguillío and Tolhuaca National Parks, with an estimated total area of $>12,000$ ha burned. In 2002 fires burned $>20,000$ ha, affecting mostly the same protected areas and other private land covered by Araucaria forests, with c. 30 and $60 \%$ of the total area of Malleco National Reserve and Tolhuaca National Park burned, respectively. As then, the 2014-2015 fires have stirred public, political and scientific concern.

Fire is an intrinsic ecological process in these forests. Fire regimes are dominated by mixed-severity fires that include low-severity surface fires and crown fires, depending on forest type and topographic location. Fires typically result in a mosaic burnt to varying degrees of severity. In the last 150 years the fire regime has changed dramatically. With the arrival of Euro-Chilean settlers human-caused fires increased, and burning and logging (until Araucaria araucana was declared a National Monument in 1976) resulted in the loss of c. $50 \%$ of the original distribution of A. araucana.

Much of the Araucaria forests are confined to national parks and reserves that are valued for their cultural and spiritual significance by the Mapuche-Pehuenche peoples, and for their biodiversity and other ecosystem services. These areas have become refuges for the Araucaria-Nothofagus forests and action is required for the prevention and control of fires. Additionally, the consumption of seeds by exotic species and domestic animals, and the unregulated collection of seeds, and ranching, by local communities affect forest regeneration, especially in early post-fire recovery. Given predictions of reduced precipitation and increased temperatures for south-central Chile, these ecosystems will be exposed to more frequent fires.

As well as recent initiatives of the Chilean forest services for the restoration of these forests, there is a need for engagement with stakeholders, communities and the wider public to establish long-term commitments and partnerships for forest conservation. This may be the biggest challenge of all.

Mauro E. González and Antonio lara Instituto de Conservación, Biodiversidad y Territorio, Universidad Austral de Chile, Valdivia, Chile

E-mailmaurogonzalez@uach.cl

\section{6th Student Conference on Conservation Science}

Nearly 180 students from 53 countries attended the 16th Student Conference on Conservation Science (SCCS) on 24-26 March 2015 in the Department of Zoology, University of Cambridge, UK. Delegates were given a warm welcome by Patricia Zurita, the new Chief Executive of BirdLife International, whose secretariat is based in Cambridge.

SCCS is an international conference series aimed entirely at young conservation scientists, so its key features are the sessions devoted to student presentations and posters. The conference avoids having a single theme, to encourage contributions that span the social and natural sciences and all taxonomic groups. The 32 student talks were interspersed with student poster sessions, with 97 posters and nine expert workshops on practical skills. Senior conservation scientists provided written feedback on all talks and posters and awarded prizes to the best three of each.

Stimulating plenary lectures were given by Julie Razafimanahaka (Madagasikara Voakajy) on resolving conservation issues in Madagascar, Patricia Majluf (Oceana) on reconciling commercial fishing with marine conservation, Tom McCarthy (Panthera) on novel and diverse approaches to promoting the co-existence of snow leopards and pastoralists, and Paul Ferraro (Georgia State University) on the standards of evidence in conservation science. Julie Razafimanahaka first attended SCCS as a student a decade ago and became the first SCCS alumnus to return as a plenary lecturer.

Social and networking events included a Who's Who in Conservation? session at which 30 conservation agencies, institutes and NGOs displayed posters and provided staff to talk about their work. Conservation practitioners play a key role in SCCS, and the conference was visited by 90 staff or representatives from 37 bodies. 